\title{
MACROECONOMIC IMPACT OF EXPENDITURES ON HIGHER EDUCATION: REGIONAL INPUT-OUTPUT ANALYSIS
}

Kristýna Vltavská ${ }^{\bowtie}$, Jakub Fischer$^{2}$

${ }^{凶 1}$ University of Economics, Prague, nam. W. Churchilla 4, 130 67, Praha 3, Czech Republic, kristyna.vltavska@vse.cz

${ }^{2}$ Department of Economic Statistics, Faculty of Informatics and Statistics, University of Economics, Prague, Czech Republic

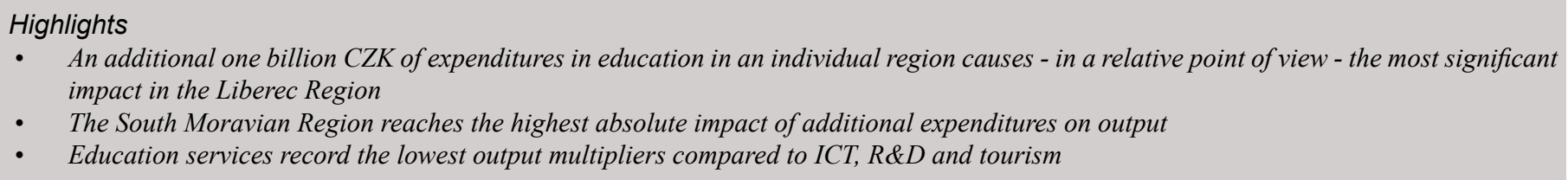

\section{Abstract}

This paper deals with the regional input-output analysis and its application to evaluation of the macroeconomic impact of expenditures on higher education. Regional input-output tables represent newly developed tool which can be used for the assessment of the regional economic impact of the particular industry and its institutions. The regional input-output tables were experimentally constructed by the Department of Economic Statistics at the University of Economics for all 14 Czech regions. Employing them, we can demonstrate the impact of expenditures on higher education on the macro-economic indicators and employment. This paper deals with 1 billion Czech crowns expenditures on higher education sent by the Ministry to the hypothetical higher education institution. Finally, the impact of higher education expenditures is compared with the impact of expenditures to another industries (ICT, $\mathrm{R} \& \mathrm{D}$ and tourism)

\section{Keywords}

ESA 1995, gross value added, higher education institution, input-output model, output, regional inputoutput tables

Vltavská K., Fischer J. (2017) "Macroeconomic Impact of Expenditures on Higher Education: Regional Input-Output Analysis", Journal on Efficiency and Responsibility in Education and Science, Vol. 10, No. 4, pp. 116-120, online ISSN 1803-1617, printed ISSN 2336-2375, doi: 10.7160/eriesj.2017.100404.

\section{Introduction}

Economic impact of education can be measured and evaluated in several ways (see Fig. 1). Mazouch and Fischer (2011) analyse the social and economic impacts of higher education for the whole economy and for the individual regions as well. There are different ways how to evaluate the impact of higher education and its institutions (HEIs) on the social and economic situation of the region. For example, Mazouch and Fischer (2011) constructed the macro-economic models which assess the impact of education level on the aggregate regional data on GDP, gross value added, labour productivity, employment, unemployment and wages etc. Education level could be measured by different approaches. Luger et al. (2001) pointed out impact of HEIs on creation of jobs (both university and non-university), attraction of students and visitors and their consequent spending, formation of human capital and development of new technologies (both with the impact on productivity increase) and also formation of regional milieu, influencing stimulation of entrepreneurial activities and attraction of high skilled workers (see Fig. 1). From his approach, we select just direct purchases of HEIs and their multiplier effects on the economy for our analysis.

Impact of production of any individual product (including educational services) could be measured, within the national accounts framework, by two main approaches. By the supply side, we can quantify the production and value added of any product and contribution to the level of GDP (so-called direct approach, direct impacts). By the expenditure (usage) side, we consider the input-output analysis which allow us to quantify the impact of change in final use (consumption, investment or export) of given product on the production side, in particular output and value added (so-called indirect approach, indirect impacts), see also OECD (2003). A short overview of recent results achieved by these approaches at the field of ICT impact analysis is brought by Fischer and Vltavská (2016b).

In this paper, we use the expenditure side impacts. Traditionally, the impact of 1 additional million or billion crown is analysed; for ICT products, see Fischer and Vltavská (2012), for tourism see Fischer et al. (2016) and for R\&D expenditures see Fischer and Vltavská (2017).

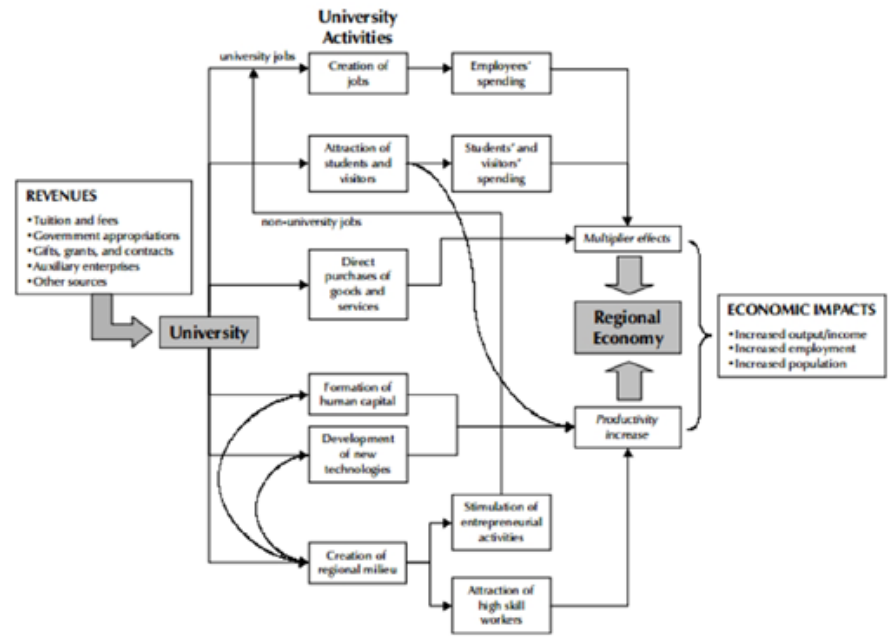

Figure 1: University impact mechanism (source: Luger et al. (2001)) Recently, the Czech tertiary education was being faced by the demographic decline (Mazouch, 2013) and the goals presented in the proposals of tertiary education reforms (Fischer and Finardi, 2010) also led to the transition of the Czech higher education "from quantity to quality". That was the reason we used in our previous research less traditional approach and tried to estimate the impact of the decline in expenditures on tertiary education 
system, represented by the closedown of one HEI (Vltavská and Fischer, 2015). This paper used input-output modelling at the national level. Using national input-output tables, it is not possible to distinguish the impact of HEI's closedown to the economy of different regions. As Sixta and Vltavská (2016) showed, the technical-economic relations differ in individual Czech regions (using NUTS 3 classification). It means that recent estimates based on national input-output tables should be improved by the regional input-output tables. As the regional tables has been experimentally estimated within the research activities at the Department of Economic Statistics (University of Economics, Prague) and published (Sixta and Vltavská, 2016), we can make this improvement. Some preliminary results for selected regions have been already published (Fischer and Vltavská, 2016a).

The aim of current paper is to estimate the macroeconomic impact of public expenditures on higher education, represented by the state support of 1 billion Czech crowns sent by the Ministry of Education, Youth and Sports to hypothetical higher education institution. The impact is estimated for almost all regions of the Czech Republic and compared to the impact of expenditures on another industries (ICT, R\&D, tourism).

The higher level of modelling the HEI's operation impact on the economy was presented by Blackwell, Cobb and Weinberg (2002). However, their approach needs very detailed set of the input data (on students, budget flows of the university, offcampus expenditures of students, parents, relatives and alumni) including some conditional data. This data set is not available for the Czech Republic although the annual reports of the HEIs are very extensive including detailed tables and although the different student surveys (e. g. EUROSTUDENT) are at a disposal.

\section{Materials and Methods}

The analysis is based on symmetric input-output tables and symmetric input-output model (Zbranek and Sixta, 2013), which represent an extension of the core of national accounts for analytical use (according to Hronová et al, 2009). Symmetric input-output tables are derived from a supply and use tables and they are compiled in two different ways - product by product and industry by industry. These two possibilities of the compilation come from the definition of the intermediate consumption matrix. The structure of the symmetric input-output tables constitute on three quadrants - intermediate consumption matrix, final usage (final consumption expenditures by institutional sectors, gross capital formation, export) and items of gross value added plus import (see Hronová et al, 2009).

Input-output model represents the discipline that is used among different groups of users. There are many analysis focused on the impact of some administration effect into the economy (Sixta and Fischer, 2015) or environment (Růžička et al, 2013) which used input-output tables of the national economy. Thus, regional input-output tables bring new possibilities how to improve such analysis just for one region of the country.

Similarly as in the previous model presented by Vltavská and Fischer (2015), we analyse the macroeconomic impact of 1 billion of money transferred to the HEIs by the Ministry of Education, Youth and Sports. The key indicators analysed are production, gross value added and compensation of employees. Moreover, the model informs about the impact into the commodity structure of the indicators mentioned. Besides, one can estimate not only the primary impact on the indicators but also the consequent impact on the decreasing final consumption expenditures. The analysis is based on 'ceteris paribus' assumption. Thus, it does not expect any other factors to the results. Detailed model and its assumptions are described by Vltavská and Fischer (2015).

For the modelling of the partial impact in individual region in the individual years we use simple static input-output model and the Leontief inversion

$$
\boldsymbol{\Delta} \mathbf{x}=\left(\mathbf{I}-\mathbf{A}_{D}\right)^{-1} \Delta \mathbf{y},
$$

where

$\Delta \mathbf{x} \ldots \ldots \ldots \ldots . . . . . .$. vector of the production change,

I .................. identity matrix,

$\mathbf{A}_{D}$............... matrix of technical coefficients which is derived from the matrix of the usage of domestic products under the intermediate consumption,

$\Delta \mathbf{y} \ldots \ldots \ldots \ldots . . . . . .$. vector of partial change of final consumption, $\left(\mathbf{I}-\mathbf{A}_{D}\right)^{-1} \ldots .$. Leontief inversion.

The model uses regional input-output tables (hereafter: RIOTs) of the year 2011 since this is the only year for which were RIOTs compiled. These tables were prepared according to the European System of Accounts ESA 1995 (Eurostat, 1996) as the project which was focused on this problem started in January 2013, i. e. before the revision of national accounts and employing standard ESA 2010. However, the methodology first published by Sixta and Vltavská (2016) is fully transferable into ESA 2010 (European Union, 2013). The significant advantage of RIOTs represents the look into the detailed structure (using Classification of Products CPA, 2 digits level) of individual region from the side of intermediate consumption, gross value added, final consumption expenditures by individual sectors, import and export (both international and interregional) etc ${ }^{1}$. As RIOTs are primarily used in regional input-output analysis they are split into imported products and domestically produced ones. It means that RIOTs of all Czech regions are divided into import matrices and RIOTs for domestic output. These tables can be used for researchers analysis as well as for the policy making decision by regional politics.

This analysis is prepared for all regions where the public HEI is located. Thus, results are prepared for 13 regions of the Czech Republic except Karlovy Vary Region where no public HEI is located. Moreover, this paper examines the changes in these regions in comparison with the results for the Czech Republic. For all regions we assume HEI with the same annual budget of one thousand million Czech crowns sent by the Ministry. The amount of 1 billion represents approximately $5 \%$ of the total budget for educational activities at public HEIs in the Czech Republic. Ministry expenditures are recorded as final consumption expenditures by government institution in particular product (CPA 85 - Education services).

\section{Results and Discussion}

Table 1 presents the overall impact of HEI on the economy. The results show that even if the ministry expenditures are the same for all regions, the impact on individual region differs. From the purely economic point of view the most significant impact (from the point of view of percentage) is recorded in the Liberec Region. The output of the region increases by $0.4 \%$ ( 1.2 bn CZK) and the final consumption expenditures increase by $1 \%$. Smaller regions where one public HEI is located increase by 0.2 or $0.3 \%$ in the output and from 0.5 to $0.8 \%$ in the final consumption expenditures. There regions covers South Bohemia, Plzen, Usti,

1 See Dept. of Economic Statistics website (in Czech): http://kest.vse. cz/veda-a-vyzkum/vysledky-vedecke-cinnosti/regionalizace-odhadu-hrubehodomaciho-produktu-vydajovou-metodou/ 
Olomouc etc. The output of regions with more than two public HEIs increases by $0.1 \%$ (approximately 1.2 bn CZK) and the final consumption expenditures increases by $0.3 \%$. The impact on the whole Czech economy (expressed as a percentage) is naturally lower.

\begin{tabular}{|l|l|r|r|r|r|r|r|r|}
\hline \multicolumn{2}{|l|}{} & CZE & Pha & Stc & \multicolumn{1}{c|}{ Jhc } & Plz & Ust & Lib \\
\hline P.1 & Output (basic prices) & 0.0 & 0.1 & 0.1 & 0.3 & 0.3 & 0.2 & 0.4 \\
\hline D.21-D.31 & Net taxes on products & 0.0 & 0.0 & 0.1 & 0.1 & 0.1 & 0.1 & 0.1 \\
\hline P.7 & Import & 0.0 & 0.0 & 0.0 & 0.0 & 0.0 & 0.0 & 0.1 \\
\hline & Resources & 0.0 & 0.1 & 0.1 & 0.2 & 0.2 & 0.1 & 0.3 \\
\hline P.2 & $\begin{array}{l}\text { Intermediate consump- } \\
\text { tion (purchasers' prices) }\end{array}$ & 0.0 & 0.0 & 0.0 & 0.1 & 0.1 & 0.1 & 0.1 \\
\hline P.3 & $\begin{array}{l}\text { Final consumption } \\
\text { expenditures }\end{array}$ & 0.0 & 0.2 & 0.3 & 0.6 & 0.7 & 0.5 & 1.0 \\
\hline P.5 & Gross capital formation & 0.0 & 0.0 & 0.0 & 0.0 & 0.0 & 0.0 & 0.0 \\
\hline P.6 & Export & 0.0 & 0.0 & 0.0 & 0.0 & 0.0 & 0.0 & 0.0 \\
\hline & Final use & 0.0 & 0.1 & 0.1 & 0.2 & 0.2 & 0.1 & 0.3 \\
\hline & & Krh & Par & Vys & Jhm & Olm & Zln & Mrs \\
\hline P.1 & Output (basic prices) & 0.3 & 0.3 & 0.3 & 0.1 & 0.3 & 0.3 & 0.1 \\
\hline D.21-D.31 & Net taxes on products & 0.1 & 0.1 & 0.1 & 0.0 & 0.1 & 0.1 & 0.1 \\
\hline P.7 & Import & 0.0 & 0.0 & 0.1 & 0.0 & 0.1 & 0.0 & 0.0 \\
\hline & Resources & 0.2 & 0.2 & 0.2 & 0.1 & 0.2 & 0.2 & 0.1 \\
\hline P.2 & $\begin{array}{l}\text { Intermediate consump- } \\
\text { tion (purchasers' prices) }\end{array}$ & 0.1 & 0.1 & 0.1 & 0.1 & 0.1 & 0.1 & 0.0 \\
\hline P.3 & $\begin{array}{l}\text { Final consumption } \\
\text { expenditures }\end{array}$ & 0.7 & 0.8 & 0.8 & 0.3 & 0.6 & 0.8 & 0.3 \\
\hline P.5 & Gross capital formation & 0.0 & 0.0 & 0.0 & 0.0 & 0.0 & 0.0 & 0.0 \\
\hline P.6 & Export & 0.0 & 0.0 & 0.0 & 0.0 & 0.0 & 0.0 & 0.0 \\
\hline & Final use & 0.2 & 0.2 & 0.2 & 0.1 & 0.2 & 0.2 & 0.1 \\
\hline
\end{tabular}

Table 1: The total macroeconomic impact of $1 \mathrm{bn}$ expenditures on HEIs, \% (source: own calculation)

Note: CZE - the Czech Republic, Pha-Prague, Stc-Central Bohemia Region, Jhc - South Bohemia Region, Plz - the Plzen Region, Ust the Usti Region, Lib - the Liberec Region, Krh - the Hradec Kralove Region, Par - the Pardubice Region, Vys - the Vysocina Region, Jhm the South Moravian Region, Olm - the Olomouc Region, Zln - the Zlin Region, Mrs - the Moravian-Silesian Region

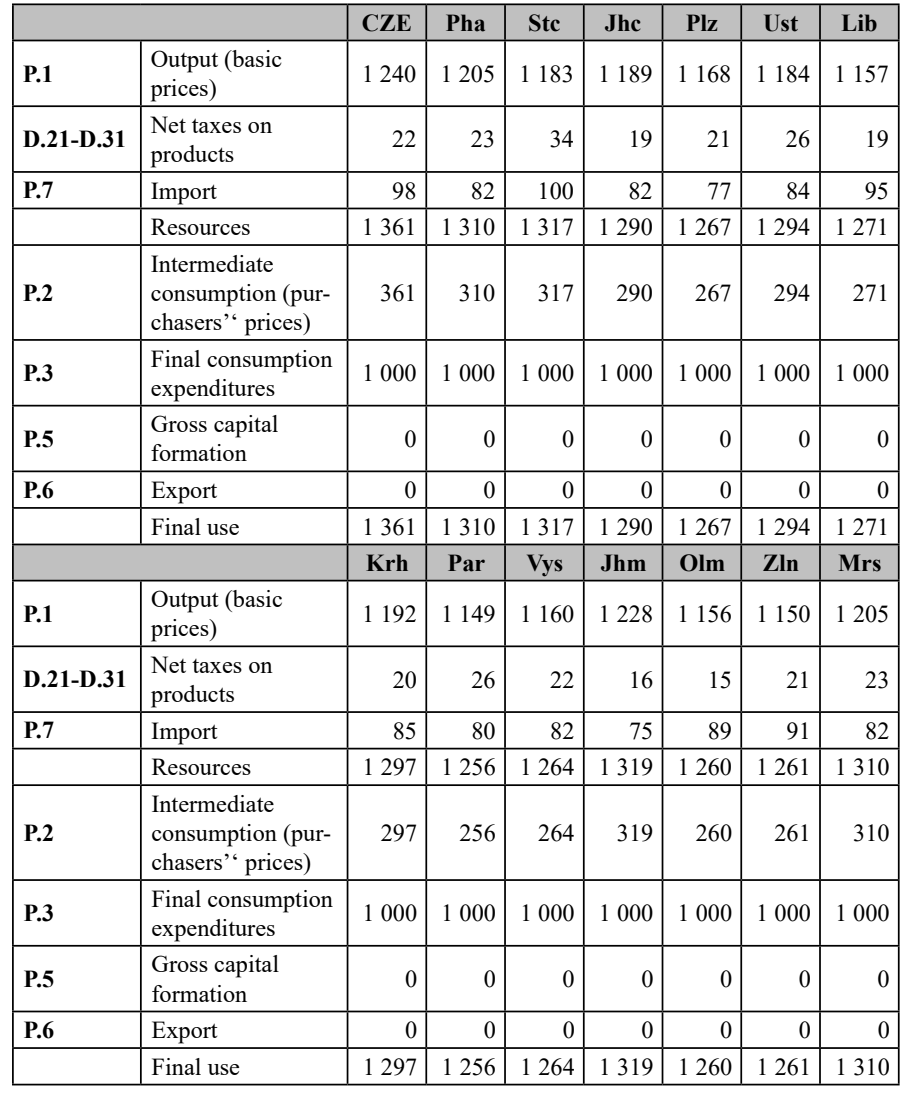

Table 2: The total macroeconomic impact of $1 \mathrm{bn}$ expenditures on HEIs, mil CZK (source: own calculation)

Table 2 presents the different look on the results: one can see the impact of 1 bn expenditures on HEIs to the absolute values of regional national accounts indicators. The highest absolute impact on the output is achieved in the South Moravian Region (1 228 mil CZK) and identically in Prague and the MoravianSilesian Region (1 205 mil CZK). In all these regions it means the increase of the output by $0.1 \%$ (table 1 ). On the contrary, the lowest increase of the output is seen in the Pardubice Region (1 149 mil CZK which means $0.3 \%$ of output).

\begin{tabular}{|c|c|c|c|c|c|c|c|}
\hline & CZE & Pha & Stc & Jhe & $\mathrm{Plz}$ & Ust & Lib \\
\hline $\mathbf{A}$ & 1 & 1 & 2 & 2 & 2 & 1 & 1 \\
\hline B to $E$ & 50 & 49 & 33 & 48 & 33 & 49 & 22 \\
\hline $\mathbf{F}$ & 22 & 20 & 20 & 19 & 17 & 18 & 18 \\
\hline $\mathbf{G}+\mathbf{H}+\mathbf{I}$ & 29 & 24 & 23 & 23 & 21 & 21 & 17 \\
\hline $\mathbf{J}$ & 17 & 15 & 10 & 10 & 11 & 11 & 9 \\
\hline $\mathbf{K}$ & 12 & 6 & 4 & 7 & 7 & 5 & 9 \\
\hline $\mathbf{L}$ & 26 & 20 & 21 & 19 & 18 & 19 & 19 \\
\hline $\mathbf{M}+\mathbf{N}$ & 33 & 26 & 25 & 23 & 23 & 21 & 22 \\
\hline $\mathbf{O}+\mathbf{P}+\mathbf{Q}$ & 1045 & 1040 & 1039 & 1035 & 1033 & 1036 & 1037 \\
\hline R to $T$ & 4 & 4 & 4 & 3 & 3 & 3 & 3 \\
\hline \multirow[t]{2}{*}{\begin{tabular}{|l|} 
Total \\
\end{tabular}} & 1240 & 1205 & 1183 & 1189 & 1168 & 1184 & 1157 \\
\hline & Krh & Par & Vys & Jhm & Olm & Zln & Mrs \\
\hline $\mathbf{A}$ & 1 & 1 & 1 & 2 & 1 & 1 & 1 \\
\hline B to $E$ & 46 & 25 & 42 & 48 & 22 & 23 & 49 \\
\hline $\mathbf{F}$ & 19 & 16 & 17 & 22 & 18 & 18 & 20 \\
\hline $\mathbf{G}+\mathbf{H}+\mathbf{I}$ & 19 & 18 & 17 & 29 & 20 & 18 & 24 \\
\hline $\mathbf{J}$ & 15 & 12 & 8 & 16 & 8 & 8 & 15 \\
\hline $\mathbf{K}$ & 9 & 7 & 4 & 10 & 6 & 5 & 6 \\
\hline $\mathbf{L}$ & 19 & 16 & 19 & 24 & 17 & 18 & 20 \\
\hline $\mathbf{M}+\mathbf{N}$ & 22 & 18 & 16 & 32 & 23 & 21 & 26 \\
\hline $\mathbf{O}+\mathbf{P}+\mathbf{Q}$ & 1038 & 1033 & 1032 & 1040 & 1036 & 1035 & 1040 \\
\hline$R$ to $T$ & 4 & 3 & 3 & 4 & 3 & 3 & 4 \\
\hline Total & 1192 & 1149 & 1160 & 1228 & 1156 & 1150 & 1205 \\
\hline
\end{tabular}

Table 3: Total change of output, mil CZK (source: own calculation) Note: A - Agriculture, forestry and fishing, B - Mining and quarrying, $C$ - Manufacturing, D - Electricity, gas, steam and air conditioning supply, $E$ - Water supply; sewerage, waste management and remediation activities, $F$-Construction, Services: $G$ - Wholesale and retail trade; repair of motor vehicles and motorcycles, $H$ - Transportation and storage, I - Accommodation and food service activities, $J$ - Information and communication, $K$ - Financial and insurance activities, $L$ - Real estate activities, $M$ - Professional, scientific and technical activities, $N$ Administrative and support service activities, $O$ - Public administration and defence; compulsory social security, $P$ - Education, $Q$ - Human health and social work activities, $R$ - Arts, entertainment and recreation, $S$ - Other service activities, $T$ - Activities of households as employers and producers for own use.

The impact of the public expenditures on HEIs differs in individual regions and industries. Table 3 illustrates the total change of output of individual industries according to the officially published regional data by the Czech Statistical Office. The Central Bohemia Region represents the region which is the closest to the average by the structure of the Czech Republic. Prague differs the most as many HEIs are located here. The most significant impact is detected among industries in which HEIs take parts (more than 1 bn CZK in each region). Thus, industries Public administration and defence $(\mathrm{O})$, Education $(\mathrm{P})$ and Human health and social work activities (Q).

Besides the structure of output, the structure of gross value added differs among regions (table 4). It is given by the availability of regional producers to satisfy specific regional demands. When analysing the impact of expenditures on HEIs, the highest impact on gross value added is investigated in the South Moravia Region (909 mil CZK) and the Plzen Region (902 mil CZK). The impact on Prague is higher (895 mil CZK) than the average of the Czech Republic ( 880 mil CZK).

Expenditures on HEIs influence not only economic indicators of individual regions but the employment as well (see also Sixta, 2017). The increase of HEI budget will mostly influence the 
employment in Prague (by 2.5 thousands persons). It represents $0.27 \%$ of employment in Prague. On the other hand, the lowest increase of employed persons in absolute value by 1.6 thousand persons is found in the Vysočina Region $(0.74 \%)$ and the South Moravian Region (0.3\%).

\begin{tabular}{|c|c|c|c|c|c|c|c|}
\hline & CZE & Pha & Stc & Jhe & Plz & Ust & Lib \\
\hline $\mathbf{A}$ & 1 & 0 & 1 & 1 & 1 & 0 & 0 \\
\hline B to $E$ & 15 & 17 & 11 & 14 & 11 & 16 & 7 \\
\hline $\mathbf{F}$ & 8 & 8 & 7 & 7 & 7 & 8 & 8 \\
\hline $\mathbf{G}+\mathbf{H}+\mathbf{I}$ & 12 & 11 & 11 & 11 & 10 & 10 & 8 \\
\hline $\mathbf{J}$ & 9 & 7 & 3 & 4 & 5 & 5 & 4 \\
\hline K & 7 & 3 & 2 & 4 & 4 & 3 & 5 \\
\hline $\mathbf{L}$ & 13 & 10 & 14 & 11 & 11 & 10 & 11 \\
\hline $\mathbf{M}+\mathbf{N}$ & 13 & 10 & 9 & 8 & 10 & 8 & 8 \\
\hline $\mathbf{O}+\mathbf{P}+\mathbf{Q}$ & 801 & 826 & 805 & 836 & 842 & 828 & 833 \\
\hline$R$ to $T$ & 2 & 2 & 2 & 2 & 2 & 2 & 2 \\
\hline \multirow[t]{2}{*}{ Total } & 880 & 895 & 866 & 898 & 902 & 890 & 886 \\
\hline & Krh & Par & Vys & Jhm & Olm & Zln & Mrs \\
\hline $\mathbf{A}$ & 1 & 0 & 0 & 1 & 1 & 0 & 0 \\
\hline B to $E$ & 17 & 10 & 13 & 15 & 8 & 8 & 17 \\
\hline $\mathbf{F}$ & 8 & 7 & 7 & 7 & 7 & 7 & 8 \\
\hline $\mathbf{G}+\mathbf{H}+\mathbf{I}$ & 9 & 8 & 9 & 13 & 9 & 9 & 11 \\
\hline $\mathbf{J}$ & 8 & 5 & 3 & 9 & 4 & 3 & 7 \\
\hline $\mathbf{K}$ & 5 & 3 & 2 & 5 & 4 & 2 & 3 \\
\hline $\mathbf{L}$ & 11 & 10 & 9 & 13 & 9 & 10 & 10 \\
\hline $\mathbf{M}+\mathbf{N}$ & 9 & 6 & 5 & 13 & 10 & 7 & 10 \\
\hline $\mathbf{O}+\mathbf{P}+\mathbf{Q}$ & 826 & 841 & 846 & 831 & 844 & 840 & 826 \\
\hline$R$ to $T$ & 2 & 2 & 2 & 3 & 2 & 2 & 2 \\
\hline Total & 895 & 893 & 896 & 909 & 896 & 889 & 895 \\
\hline
\end{tabular}

Table 4: The total impact of 1 bn expenditures on HEIs on gross value added, mil CZK (source: own calculation)

\begin{tabular}{|l|c|r|r|r|r|r|r|}
\hline & Pha & Stc & \multicolumn{1}{l|}{ Jhc } & Plz & Ust & Lib & Krh \\
\hline persons & 2452 & 1945 & 1762 & 1726 & 2049 & 1825 & 1375 \\
\hline \% & 0.27 & 0.35 & 0.59 & 0.62 & 0.58 & 0.94 & 0.55 \\
\hline & Par & \multicolumn{1}{|l|}{ Vys } & Jhm & Olm & Zln & Mrs & \\
\hline persons & 1757 & 1654 & 1654 & 1689 & 1752 & 1778 & \\
\hline \% & 0.75 & 0.74 & 0.30 & 0.62 & 0.67 & 0.34 & \\
\hline
\end{tabular}

Table 5: The total impact 1 bn expenditures on HEIs on employment, persons, \% (source: own calculation)

Output multipliers present other result of the input-output analysis. Multipliers present the importance of backward linkage of individual industry in each region. For the illustration we present multipliers of CPA 85 (Education services). The results show (Table 6) that the strongest backward linkage in education reach the South Moravian Region, Prague and Moravian-Silesian Region (around 1.2). On the contrary, the weakest linkage reach the Pardubice Region and the Vysočina Region (1.5). The multiplier in the South Bohemian Region says that 1 mil. CZK invested into the education lead to the increase of output in the South Bohemian Region by 1.2 mil. CZK.

Finally, we can compare the multipliers of HEIs educational expenditures with multipliers estimated within our previous research, see Fischer and Vltavská (2012), Fischer et al. (2016) Fischer and Vltavská (2017).

The output multipliers are the lowest for the education services, also with the lowest absolute differences between regions. The reason consists in fact that education services have the highest share of compensations of employees and on the contrary the lowest share of the intermediate consumption on the gross value added. And just the intermediate consumption has the key effect at the multiplication process, because the purchases of goods and services used as intermediates lead to the production at other industries. The highest multipliers are estimated for Prague and the South Moravia Region, where many education institutions provide the services and part of them is out-sourced from another institutions. Multiplying effect in Prague also leads to the highest impact on employment (see table 5).

\begin{tabular}{|c|c|c|c|r|r|c|c|c|c|}
\hline \multirow{2}{*}{ Region } & \multicolumn{3}{|c|}{ ICT } & \multicolumn{1}{c|}{ R\&D } & \multicolumn{1}{|c|}{ Education } & \multicolumn{4}{|c|}{ Tourism } \\
\cline { 2 - 10 } & $\mathbf{2 6}$ & $\mathbf{6 1}$ & $\mathbf{6 2}$ & \multicolumn{1}{|c}{} & $\mathbf{8 5}$ & $\mathbf{5 5}$ & $\mathbf{5 6}$ & $\mathbf{7 9}$ & $\mathbf{9 3}$ \\
\hline Pha & 1.25 & 1.38 & 1.48 & 1.47 & 1.21 & 1.92 & 1.51 & 2.18 & 2.05 \\
\hline Stc & 1.23 & 1.26 & 1.61 & 1.40 & 1.18 & 1.77 & 1.56 & 1.96 & 1.86 \\
\hline Jhc & 1.19 & 1.31 & 1.53 & 1.24 & 1.19 & 1.71 & 1.55 & 2.00 & 2.00 \\
\hline Plz & 1.37 & 1.28 & 1.44 & 1.39 & 1.17 & 1.84 & 1.59 & 2.07 & 2.02 \\
\hline Ust & 1.26 & 1.39 & 1.55 & 1.87 & 1.18 & 1.96 & 1.52 & 1.98 & 1.98 \\
\hline Lib & 1.18 & 1.22 & 1.51 & 1.62 & 1.16 & 1.65 & 1.40 & 1.94 & 1.98 \\
\hline Krh & 1.21 & 1.38 & 1.47 & 1.74 & 1.19 & 1.62 & 1.51 & 1.92 & 1.86 \\
\hline Par & 1.29 & 1.52 & 1.64 & 1.81 & 1.15 & 1.68 & 1.46 & 1.82 & 1.92 \\
\hline Vys & 1.19 & 1.20 & 1.53 & 1.54 & 1.16 & 1.75 & 1.49 & 1.86 & 1.87 \\
\hline Jhm & 1.36 & 1.46 & 1.41 & 1.36 & 1.23 & 1.85 & 1.72 & 2.20 & 2.23 \\
\hline Olm & 1.18 & 1.23 & 1.51 & 1.67 & 1.16 & 1.78 & 1.58 & 2.02 & 1.96 \\
\hline Zln & 1.23 & 1.22 & 1.48 & 1.28 & 1.15 & 1.66 & 1.49 & 1.92 & 1.90 \\
\hline Mrs & 1.25 & 1.38 & 1.48 & 1.47 & 1.21 & 1.92 & 1.51 & 2.18 & 2.05 \\
\hline
\end{tabular}

Table 6: Output multipliers, 2011 (source: own calculation)

Note: 26 - Computer, electronic and optical products, 55 Accommodation services, 56 - Food and beverage serving services, 61 - Telecommunications services, 62 - Computer programming, consultancy and related services, 72 - Scientific research and development services, 79 - Travel agency, tour operator and other reservation services and related services, 85 - Education services, 93 Sporting services and amusement and recreation services

Among ICT industries, the lowest level of multipliers at NACE 26 (Computer, electronic and optical products) is influenced by the high share of imports on production (which causes lower domestic multipliers; multiplication effect is realised abroad). In terms of multiplication effect, $R \& D$ expenditures are better than education expenditures (at $R \& D$, more material and services should be purchased comparing to education). In tourism, the most efficient is multiplication within traveling and recreation comparing to food and accommodation services. It is also caused by the structure of gross value added and the structure of intermediate consumption.

\section{Conclusion}

The aim of this paper was to estimate the indirect impacts of the Czech tertiary education on the economy of the Czech regions, as the example of usage of recently developed regional inputoutput tables. Using this approach, we estimated the impact of expenditures on higher education institutions and the small differences within the Czech Republic. Comparing the results we can conclude, that the most significant impact of HEI's operation is for the South Moravia Region in terms of absolute changes of the total output and total gross value added of the region.

These results detects only purely macroeconomic impact of higher education expenditures on the regions. Further analysis should be focused on wider social and economic impacts. Nevertheless, recently estimated regional input-output tables seem to be a very useful tool for economic analysis of the Czech regions and for such regional industry impact analysis.

At the end of our paper, we compare multipliers of another selected industries, investigated within our previous research. Multipliers estimated for education services are lower than the ones for ICT Services, R\&D expenditures and tourism.

\section{Acknowledgements}

This paper is prepared under the support of the project "Regional estimates of gross domestic product based on the expenditure approach" of the Czech Science Foundation, project No. 13$15771 \mathrm{~S}$ and by Institutional Support for Long Period and Conceptual Development of Research and Science at Faculty of Informatics and Statistics, University of Economics, Prague. 


\section{References}

Blackwell, M., Cobb, S. and Weinberg, D. (2002) 'The economic impact of educational institutions: Issues and methodology' Economic Development Quarterly, Vol. 16, No. 1, pp. 88-95. http://dx.doi.org/10.1177/0891242402016001009

European Union (2013) European System of Accounts ESA 2010, Luxembourg: Publications Office of the European Union. Eurostat (1996) European System of Accounts ESA 1995, Luxembourg: Publications Office of the European Union.

Fischer, J. and Finardi, S. (2010) 'Czech tertiary education on the way to competitiveness', Proceedings of the International Conference Interdisciplinary Information Management Talks. Linz, pp. 231-236.

Fischer, J., Kramulová, J. and Vltavská, K. (2016) Cestovní ruch $v \check{C} R$ : makroekonomické dopady, marketingové plány, efektivita marketingových výdajů [Tourism in the Czech Republic: macroeconomic impacts, marketing plans, efficiency of marketing expenditures]. [Comprehensive research report] Fischer, J. and Vltavská, K. (2017) Analýza efektivity veřejných výdaju na výzkum a vývoj na národni i regionálni úrovni [Analysis of the effectiveness of $R \& D$ public expenditures at the national and regional level]. [Comprehensive research report] Fischer, J. and Vltavská, K. (2012) 'Intermediate Consumption of ICT Products and Its Impact on Economy of the Czech Industries', Proceedings of the International Conference Interdisciplinary Information Management Talks. Prague, pp. 115-121.

Fischer, J. and Vltavská, K. (2016a) 'Regional Impact of HEI's Closedown: Methods of Quantification Using RIOT', Proceedings of the International Conference Efficiency and Responsibility in Education. Prague, pp. 134-140.

Fischer, J. and Vltavská, K. (2016b) 'Regional Input-Output Tables as a Data Source for ICT Economic Impact Analysis', Proceedings of the International Conference Interdisciplinary Information Management Talks. Linz, pp. 29-36.

Hronová, S., Fischer, J., Hindls, R., Sixta, J. (2009) National Accounts (As a Tool for Describing the Global Economy), Prague: C. H. Beck.

Luger, M., Koo, J., Perry, J. and Billings, S. (2001) The Economic Impact of the UNC System on the State of North Carolina, The University of North Carolina at Chapel Hill.

Mazouch, P. (2013) 'The University Graduation Rate: Trends and Levels', Proceedings of the International Days of Statistics and Economics. Prague, pp. 977-983.

Mazouch, P. and Fischer, J. (2011) Human capital, Prague: C.H. Beck.

OECD (2003) ICT and Economic Growth, OECD, Paris.

Růžička, P., Harnych, J., Spitz, J., Klicpera, J., Pelcl, L., Filipovský, J., Potočka, Z., Šafr, K., Vojáček, O., Sobotka, L. and Smejkal, T. (2013) Ekonomická analýza environmentálně energetické legislativy a regulativy ve vztahu ke konkurenceschopnosti českého průmyslu s doporučením pro dalši postup, [Online], Available: www.socialnidialog.cz/ images/stories/Analyzy/Analyza_Enviro.pdf [1 Dec 2017]

Sixta, J. (2017) 'Input-Output Approach to Regional Employment', Statistika, Vol. 97, No. 1, pp. 5-17.

Sixta, J. and Fischer, J. (2015) 'Regional Input-Output Models: Assessment of the Impact of Investment in Infrastructure on the Regional Economy', Proceedings of the Mathematical Methods in economics. Plzeň, pp. 719-724.

Sixta, J. and Vltavská, K. (2016) 'Regional Input-Output Tables: Practical Aspects of its Compilation for the Regions of the Czech Republic', Ekonomický časopis, Vol. 64, No. 1, pp. 56-69.

Vltavská, K. and Fischer, J. (2015) 'When the ministry closes a public HEI: expected impacts on economy', Proceedings of the International Conference Efficiency and Responsibility in Education. Prague, pp. 604-610.

Zbranek, J. and Sixta, J. (2013) 'Posibilities of Time InnputOutput Tables', Proceedings of Mathematical Methods in Economics. Jihlava, pp. 1046-1051 